\title{
Effect of arbuscular mycorrhizal inoculation on the quality and in vitro gas production of einkorn wheat straw
}

\author{
T. Ayaşan ${ }^{1 \#}$, E. Cabi ${ }^{2}$, S. Esen ${ }^{3}$, V.K. Esen ${ }^{3} \&$ H. Eseceli ${ }^{4}$ \\ ${ }^{1}$ Osmaniye Korkut Ata University, Kadirli Academy of Applied Sciences, Osmaniye, Turkey \\ ${ }^{2}$ Tekirdağ Namık Kemal University, Department of Biology, Tekirdağ, Turkey \\ ${ }^{3}$ Bandırma Sheep Research Institute, Bandırma, Turkey \\ ${ }^{4}$ Bandirma Onyedi Eylül University, Bandırma, Turkey
}

(Submitted 18 April 2020; Accepted 6 May 2020; First published online 21 June 2020)

\author{
Copyright resides with the authors in terms of the Creative Commons Attribution 4.0 South African Licence. \\ See: http://creativecommons.org/licenses/by/4.0/za \\ Conditions of use: The user may copy, distribute, transmit and adapt the work, but must recognise the authors and the South African \\ Journal of Animal Science.
}

\begin{abstract}
The purpose of this study was to determine the effects of arbuscular mycorrhizal (AM) inoculation on the quality of einkorn wheat straw (EWS) and in vitro gas production (GP). It was found that AM inoculation of EW seed before sowing caused significant increases in crude protein (CP), ether extract (EE), neutral detergent fibre (NDF), zinc $(\mathrm{Zn})$, copper $(\mathrm{Cu})$, and iron $(\mathrm{Fe})$ levels of straw, and a $(P<0.05)$ decrease in crude ash (CA), metabolizable energy (ME), and organic matter digestibility (OMD) compared with the straw of non-inoculated EW. The observed difference in the average GP among the between EWS from plants grown from inoculated seed and those from the untreated control was significant at all times between the third and 96th hour. However, when the GP kinetics of the groups was examined after 96 hours' incubation, only the difference in the gas amount of the easily soluble fractions of feeds was significant. The GP from the slowly fermented part, the GP rate constant and the potential GP of the straws were not affected by the AM inoculation $(P>0.05)$. Thus, inoculation of einkorn wheat with $\mathrm{AM}$ altered the nutritional value of the straw produced creating a roughage with decreased value for feeding ruminant livestock.
\end{abstract}

Keywords: artificial rumen, fermentation kinetics, nutrient digestibility

\# Corresponding author: tayasan@gmail.com

\section{Introduction}

Wheat is an energy-based feed material that is used in human and animal nutrition. Various studies have been carried out on bread and durum wheat varieties and their properties (e.g. Ayaşan et al., 2017; Ergül et al., 2017). Einkorn wheat is accepted as the ancestor of all wheat varieties. Its most important form is the cultivated hulled variety. Unlike modern wheats, einkorn wheat is a diploid species $(2 n=14$ chromosomes). With its tight hull structure and a single spikelet, it is resistant to disease and pests, and is highly competitive in arid conditions. It is also rich in B-group vitamins.

Straws are low-quality feeds that are used as sources of roughage in animal feeding. Therefore, in order to improve diet quality, studies have been carried out on various roughages as alternatives to wheat straw (Ülger et al., 2017; Beyzi et al., 2018; Ülger et al., 2018; Zheng et al., 2018; Tang et al., 2019; Hart, 2020). Physical, chemical, and biological treatments are also administered to increase the nutrient quality of straw (Shrivastava et al., 2014; Zayed, 2018).

Arbuscular mycorrhizal fungi are naturally ubiquitous beneficial microorganisms in agricultural ecosystems. These microorganisms form a symbiotic relationship with plant roots and provide plants with minerals and nutrients in exchange for photosynthetically fixed carbon (Pellegrino et al., 2015; Somenahallya et al., 2018). They enhance the growth and yield of agriculturally important crops by increasing their mineral intake, disease resistance and drought tolerance. In their study, which examined the effects of adding the AM fungi to wheat, Pellegrino et al. (2015) asserted that AM inoculation fungi could be an effective agronomic application and would prove economically useful in large-scale treatments. Sabia et al. (2015) stated that barley inoculated with mycorrhiza had more CP than the control group, but less ADL and ADL, and the positive effect of mycorrhizal inoculation on the chemical composition of barley was its increased 
ability to fight stress. It has been suggested that many plant species benefit from the natural mechanisms of beneficial microorganisms in the soil, especially mycorrhiza fungi (Akpınar, 2011). Smith and Read (2008) found that when mycorrhiza had an effective symbiotic relationship with plant roots, the plant increased its intake of water and mineral nutrients such as potassium $(P)$, zinc $(\mathrm{Zn})$, and copper $(\mathrm{Cu})$. Therefore, the purpose of this study was to understand the effect of AM inoculation on the quality and GP of EWS.

\section{Materials and Methods}

An AM fungal inoculation trial was conducted at a private farm in Pinarbasi (41.5549 N, 33.1074 E) Kastamonu, Turkey, in November 2018. A total 5 ha was cultivated with einkorn wheat, of which 4.5 ha was used as the control group and 0.5 ha for AM fungal application. Glomus spp., collected from the rhizosphere soil of maize plants, was used as an AM fungal inoculant. Collected spores was identified according to their morphological characteristics described by Schenck and Perez (1990), For the seed coating procedure, Glomus spp. was mixed with silicon dioxide $(1: 1 \mathrm{w} / \mathrm{w})$, which served as coating material (Merck, Darmstadt, Germany). Abnormal grains of EW were removed prior to coating. The seed was then coated by gradually adding the inoculum-coating mixture and air dried at $24 \pm 2{ }^{\circ} \mathrm{C}$ for $72 \mathrm{~h}$ according to the pan coating method (Scott et al., 1991). Non-inoculated control seeds of EW were coated only with silicon dioxide. The crop was harvested in July 2019 with a combine. Samples of EWS and EWS plus arbuscular mycorrhizal (IEWS) were obtained as crop residues after harvesting for grain in July 2019. Samples were collected randomly in three blocks via three replicates. Samples were field dried and milled through a 1-mm sieve in a laboratory and stored in plastic bags for subsequent chemical analysis, and determination of selected mineral concentrations and in vitro gas production.

The samples were analysed using AOAC methods (AOAC, 1990) to determine their DM, CP, CA, EE, and CF concentrations. The NDF, ADF, and acid detergent lignin (ADL) contents were determined according to the methods reported in Van Soest et al. (1991).

Approximately $0.5 \mathrm{~g}$ of a sample was weighed into a vessel that was resistant to temperature and pressure, with $8 \mathrm{~mL}$ nitric acid $\left(\mathrm{HNO}_{3}\right)$ and $2 \mathrm{~mL}$ of hydrogen peroxide $\left(\mathrm{H}_{2} \mathrm{O}_{2}\right)$ for microwave digestion. The digested sample was then allowed to cool before being transferred quantitatively into clean Falcon tubes, completed to $25 \mathrm{~mL}$ final volume with deionized water and analysed with a Shimadzu AA-7000 (Shimadzu Corporation, Kyoto, Japan) flame atomic absorption spectrophotometer (Milestone, 2009). All chemical analyses were carried out in triplicate.

In vitro gas production of EWS and IEWS samples was measured with the ANKOMRF gas production system (ANKOM Technology, Macedon, New York, USA). Twenty millilitres of particle-free rumen fluid was added to each bottle and then $80 \mathrm{~mL}$ of the buffer solution (Goering \& Van Soest, 1970) without trypticase. The rumen fluid was obtained from goats that had been freshly slaughtered at the local slaughterhouse and was filtered through four layers of cheesecloth into a pre-warmed thermos and transferred to the laboratory within 20 minutes. Anaerobic conditions were maintained throughout the preparation stages of the rumen fluid and the experiment. All equipment was pre-warmed to $39^{\circ} \mathrm{C}$ before $100 \mathrm{~mL}$ rumen fluid-buffer mixture (1: 4) was injected into each $250 \mathrm{~mL}$ bottle. Three repetitions of each sample were used in the GP experiment. All glass bottles containing incubation medium and feed samples were incubated for 96 hours with GP recorded at $0,3,6,12,24,48,72$, and 96 hours. Total gas values were corrected for GP in bottles without feedstuff added.

Cumulative gas production data were fitted to the model of Orskov \& McDonald (1979) by the TableCurve 2D Version 5.01 (Systat Software, Inc., San Jose, California, USA):

$$
Y=a+b\left(1-e^{-c t}\right)
$$

Where: $Y=$ gas produced at time $t(\mathrm{~h})$,

$a=$ gas production from the immediately soluble fraction $(\mathrm{mL})$,

$b=$ gas production from the insoluble fraction $(\mathrm{mL})$, and

$c=$ gas production rate constant for the insoluble fraction $(\mathrm{mL} / \mathrm{h})$.

Metabolizable energy (MJ/kg DM) content and organic matter digestibility (OMD) (\%) of the feedstuffs were estimated from the measured pressure of gas produced at 24 hours using these equations of Menke \& Steingass (1988):

$$
\begin{gathered}
\mathrm{ME}(\mathrm{MJ} / \mathrm{kg} \mathrm{DM})=2.20+0.1357 \times \mathrm{XP}+0.057 \times \mathrm{CP}+0.002859 \times \mathrm{EE}^{2} \\
\mathrm{OMD}(\%)=14.88+0.8893 \times \mathrm{GP}+0.448 \times \mathrm{CP}+0.651 \times \mathrm{CA}
\end{gathered}
$$


One-way analysis of variance (ANOVA) was performed using SAS-JMP 13.2 (SAS Institute Inc, Cary, North Carolina, USA) to determine the significance of treatment effects on nutritive value, selected mineral concentration, gas production, metabolizable energy and organic matter digestibility. Significance of differences between individual means was identified using a $t$-test. Differences were considered significant at $P \leq 0.05$.

\section{Results and Discussion}

Nutrient analyses were carried out on EWS and straw from einkorn wheat grown from arbuscular mycorrhiza inoculated seed (IEWS). When the treatments were compared (Table 1), it was found that the DM and CF contents were not different. However, the CP, EE, and NDF contents of the treated straw were increased as a result for the treatment $(P<0.05)$. Einkorn wheat differs from bread and durum wheat in its nutrient composition. Its grain has approximately $11.83 \% \mathrm{CP}, 1.75 \%$ ash, $1.8 \% \mathrm{EE}, 0.59 \% \mathrm{CF}, 1.19 \%$ ADF, $3.82 \%$ NDF, and $0.29 \%$ ADL (Şanal, 2018). Emeksizoğlu (2016) reported that einkorn wheat grain contained $14.83 \% \mathrm{CP}, 2.19 \% \mathrm{CF}$, and $2.48 \%$ ash. The cellulose and hemicellulose contents of wheat straw were previously reported as $36.6-47.8 \%$ and $23.6-28,1 \%$, respectively (Mishra et al., 2020). Bölükbaş and Kaya (2018) reported that wheat straw contained $90.20-92.07 \% \mathrm{DM}, 3.00-3.63 \% \mathrm{CP}, 0.29-1.77 \% \mathrm{EE}, 5.84-$ 9.60\% CA, $38.07-45.53 \%$ CF, $74.30-84.04 \%$ NDF, and $49.50-57.50 \%$ ADF. In a study by Sabia et al. (2015), the DM contents of mycorrhizal-inoculated barley and of non-inoculated barley were similar (21.2\%), a result which supports the current findings.

Table 1 Nutrient analysis of einkorn wheat straw grown with and without and arbuscular mycorrhiza inoculant

\begin{tabular}{lcccc}
\hline & EWS & IEWS & SE & $P$-value \\
\hline DM (\%) & 97.50 & 97.92 & 0.23 & 0.2250 \\
CP (\%DM) & $1.76^{\mathrm{b}}$ & $2.08^{\mathrm{a}}$ & 0.05 & 0.0006 \\
$\mathrm{EE}(\% \mathrm{DM})$ & $0.99^{\mathrm{b}}$ & $1.16^{\mathrm{a}}$ & 0.04 & 0.0257 \\
$\mathrm{CF}(\% \mathrm{DM})$ & 41.11 & 41.42 & 0.39 & 0.5775 \\
$\mathrm{CA}(\% \mathrm{DM})$ & $10.62^{\mathrm{a}}$ & $9.79^{\mathrm{b}}$ & 0.08 & $<0.0001$ \\
$\mathrm{NDF}(\% \mathrm{DM})$ & $73.88^{\mathrm{b}}$ & $77.15^{\mathrm{a}}$ & 0.50 & 0.0004 \\
$\mathrm{ADF}(\% \mathrm{DM})$ & 57.07 & 57.40 & 0.57 & 0.6869 \\
$\mathrm{ADL}(\% \mathrm{DM})$ & 8.29 & 8.29 & 0.19 & $>0,9999$ \\
$\mathrm{Zn}(\mathrm{mg} / 100 \mathrm{~g})$ & $0.84^{\mathrm{b}}$ & $0.87^{\mathrm{a}}$ & 0.009 & 0.0074 \\
$\mathrm{Cu}(\mathrm{mg} / 100 \mathrm{~g})$ & $0.33^{\mathrm{b}}$ & $0.36^{\mathrm{a}}$ & 0.003 & $<0.0001$ \\
$\mathrm{Fe}(\mathrm{mg} / 100 \mathrm{~g})$ & $6.40^{\mathrm{b}}$ & $7.04^{\mathrm{a}}$ & 0.113 & 0.0013 \\
$\mathrm{Na}(\mathrm{mg} / 100 \mathrm{~g})$ & $17.50^{\mathrm{b}}$ & $41.70^{\mathrm{a}}$ & 7.913 & 0.0484 \\
$\mathrm{~K}(\mathrm{~g} / 100 \mathrm{~g})$ & 0.77 & 0.76 & 0.018 & 0.6036 \\
$\mathrm{ME}(\mathrm{MJ} / \mathrm{kg} \mathrm{DM})$ & $4.86^{\mathrm{a}}$ & $4.18^{\mathrm{b}}$ & 0.20 & 0.0291 \\
$\mathrm{OMD}(\%)$ & $33.08^{\mathrm{a}}$ & $28.64^{\mathrm{b}}$ & 1.28 & 0.0275 \\
\end{tabular}

EWS: einkorn wheat straw grown without inoculant, IEWS: einkorn wheat straw grown with inoculant, DM: dry matter, CP: crude protein, EE: ether extract, CF: crude fibre, CA: crude ash, NDF: neutral detergent fibre, ADF: acid detergent fibre, Zn: zinc, Cu: copper, Fe: iron, Na: sodium, K: potassium, ME: metabolizable energy, OMD: organic matter digestibility

Kalkan \& Filya (2011) found the DM content of straw from untreated wheat was $92.87 \%$, whereas in the current study it was $97.50 \%$. In the current study, the IEWS had a reduced CA content in comparison to EWS $(P<0.05)$. Zheng et al. (2018) reported that wheat straw contained $89.97 \%$ DM, $9.70 \% \mathrm{CA}, 33.70 \%$ cellulose, $19.1 \%$ hemicellulose, and 19.8\% lignin; and Mishra et al. (2020) found the CA content of wheat straw to be between $5.2 \%$ and $7.1 \%$.

Barley is another grain the straw from which is commonly used as roughage for ruminant livestock. Sabia et al. (2015) studied AM inoculation of barley and clover seeds and its effect on in vivo digestibility was examined in goats. These researchers reported that the AM-inoculated barley from AM inoculated seed contained more CP $(9.5 \%$ vs. $8.1 \%$, respectively) and NDF ( $49.6 \%$ vs. $49.5 \%$, respectively), compared with 
the barley grown from non-inoculated seed. Likewise, these researchers observed that berseem clover grown from mycorrhizal-inoculated seed contained more CP (12.7\%) than clover grown from non-inoculated seed (12.2\%). Thus, it was concluded that Mycorrhizal inoculation played an important role in improving the roughage quality in barley by reducing $A D F$ and $A D L$ and preventing a significant reduction in the amount of CP. The EE content of both the barley $(1.2 \%)$ and berseem clover $(1.3 \%)$ was not changed as a result of the inoculation. Sabia et al. (2015) also found that the mycorrhizal-inoculated barley had numerically less $(P>$ $0.05)$ CF $(25.7 \%)$ than the non-inoculated one (26.0\%). In contrast, the mycorrhizal-inoculated berseem clover (17.6\%) had more CF content than the non-inoculated one (16.5\%).

Although the difference between the treatment groups in ADF content was not significant, the NDF contents differed between treatments $(P<0.05)$. Acid detergent fibre contains cellulose, lignin, and insoluble ash (mainly silica); whereas, NDF contains hemicellulose, cellulose, lignin, and insoluble ash. Thus, the difference between NDF and ADF is a measure of hemicellulose content and ADF can be estimated by subtracting hemicellulose content from the NDF content of the ground and dried feed material. Neutral detergent fibre is a good indicator of "bulk" and thus feed intake. Acid detergent fibre is a good indicator of digestibility and thus energy intake. Digestibility and energy values of feeds with high ADF content are low. In the present study, the NDF content was less in the EWS treatment than in the IEWS treatment. Kalkan and Filya (2011) found that the NDF content of untreated wheat straw was nearly $8 \%$ greater than was observed in the current study, but that its ADF content was $53.27 \%$, a value that is only a few percentage points less than that observed in this study.

Acid detergent lignin, which affects the animal's ability to digest the grass, was unchanged by AM inoculation. Although, Kalkan and Filya (2011) found the ADL content of untreated wheat straw to be much higher (12.16\%) than was observed here (Table 1). In addition, Sabia et al. (2015) found the ADL content of the straw grown from mycorrhizal-inoculated seed was reduced to $3.2 \%$ compared with the control which contained $4.3 \%$ ADL. .

Pellegrino et al. (2015) found that AM inoculation increased the biomass of straw and played an important role in increasing grain yield in maturity. In contrast, Hu et al. (2014) found that inoculation with AM G. caledonium significantly $(P<0.05)$ increased the root biomass of wheat and root-to-straw ratio but had no significant effects on shoot biomass or grain yield.

The mineral content of straw may also be modified by AM inoculation (Table 1). Here, the zinc, copper, iron, and sodium concentrations were all increased in the straw of barley that was grown from AM inoculated seed relative to the control. Pellegrino et al. (2015) asserted that AM inoculation increased the $\mathrm{Zn}$ content in the grain by $10 \%$. These authors also suggested that AM inoculation increased the nitrogen and phosphorus $(P)$ contents in the grain by $31 \%$ and $20 \%$, respectively, although the $P$ content of the wheat straw was increased $51 \%$. They also reported that $A M$ inoculation in the field increased the $\mathrm{P}$ concentration of the above ground biomass, including the straw, significantly.

Metabolizable energy was estimated with an equation using the amount of gas produced in the current study. It was highest in the control group which was grown from untreated seed (Table 1). The digestibility of organic matter was likewise higher for the control.

Application of the AM treatment created caused less gas to be produced times compared with the untreated control $(P<0.05$; Table 2). Reasons for these differences in gas production are unclear. The increased protein content and the decreased NDF content would be expected to increase gas production.

Table 2 Gas produced over time by in vitro digestion of einkom wheat straw grown with and without and arbuscular mycorrhiza inoculant

\begin{tabular}{lccccccc}
\hline & $3 \mathrm{~h}, \mathrm{~mL}$ & $6 \mathrm{~h}, \mathrm{~mL}$ & $12 \mathrm{~h}, \mathrm{~mL}$ & $24 \mathrm{~h}, \mathrm{~mL}$ & $48 \mathrm{~h}, \mathrm{~mL}$ & $72 \mathrm{~h}, \mathrm{~mL}$ & $96 \mathrm{~h}, \mathrm{~mL}$ \\
\hline EWS & $3.93^{\mathrm{a}}$ & $5.69^{\mathrm{a}}$ & $6.66^{\mathrm{a}}$ & $18.81^{\mathrm{a}}$ & $43.25^{\mathrm{a}}$ & $57.42^{\mathrm{a}}$ & $69.05^{\mathrm{a}}$ \\
IEWS & $1.58^{\mathrm{b}}$ & $1.51^{\mathrm{b}}$ & $3.35^{\mathrm{b}}$ & $13.70^{\mathrm{b}}$ & $36.42^{\mathrm{b}}$ & $49.28^{\mathrm{b}}$ & $59.17^{\mathrm{b}}$ \\
$\mathrm{SE}$ & 0.26 & 0.40 & 0.73 & 1.53 & 1.77 & 2.10 & 2.17 \\
$P$-Value & $<0.0001$ & $<0.0001$ & 0.0074 & 0.0362 & 0.0185 & 0.0178 & 0.0073 \\
\hline
\end{tabular}

EWS: einkorn wheat straw grown without inoculant, IEWS: einkorn wheat straw grown with inoculant

The kinetics of the treatment groups were examined over the 96 hours of incubation. Parameter estimates describing the gas produced are given in Table 3. Instantaneous gas production $(a)$, reflecting the 
volume of gas $(\mathrm{ml})$ formed at the moment that the feed was put into the artificial rumen, differed between the treatments. The values $(a+b)$, which refers to the potential gas production of feeds and $(b)$, which refers to the gas amount obtained from the slowly fermented part, were not different between the treatments.

Table 3 Parameter estimates describing temporal kinetics of in vitro gas production of einkom wheat straw grown with and without and arbuscular mycorrhiza inoculant

\begin{tabular}{lcccc}
\hline & $c$ & $a$ & $b$ & $a+b$ \\
\hline EWS & 0.0067 & $-1.17^{\mathrm{a}}$ & 156.59 & 155.42 \\
IEWS & 0.0540 & $-2.75^{\mathrm{b}}$ & 148.74 & 145.99 \\
SE & 0.0010 & 0.22 & 12.11 & 12.24 \\
$P$-Value & 0.3670 & 0.0003 & 0.6548 & 0.5962
\end{tabular}

EWS: einkorn wheat straw grown without inoculant, IEWS: einkorn wheat straw grown with inoculant, $a$ : immediate gas production for the soluble fraction $(\mathrm{mL}), b$ : gas production from the insoluble fraction $(\mathrm{mL}), c$ : gas production rate constant

\section{Conclusions}

Inoculation of einkorn wheat with AM altered the nutritional value of the straw produced creating a roughage with decreased value for feeding ruminant livestock. However, its degradation in the rumen may require more time than straw from untreated wheat.

\section{Acknowledgements}

The authors would like to thank Mr. N. Bodur for the cooperation during to field trial.

\section{Authors' Contributions}

SE and VKE contributed to the project idea, design and execution of the study. EC and HE conducted the laboratory analyses. TA supervised the experiment and wrote the manuscript.

\section{Conflict of Interest Declaration}

The authors have declared that that there are no competing interests.

\section{References}

Akpınar, C., 2011. The effects of mycorrhizae inoculation on yield and nutrient uptake of canola following by maize. Çukurova Üniversitesi Fen Bilimleri Enstitüsü Toprak Bilimi ve Bitki Besleme ABD, PhD thesis. P. 185, Adana, Turkey.

AOAC (Association of Official Analytical Chemists), 1990. Official methods of analysis. 15th edition. Washington DC, USA.

Ayaşan, T., Ülger, I., Baylan, M., Dinçer, M. N., Barut, H., Aykanat, S., Erten, H.E., Ezìcì, A.A., Yaktubay, S. \& Mizrak, C., 2017. Determination of the nutritive value of some durum wheat (Triticum durum L.) varieties developed using in vitro gas production technique. Iğdır Üniversitesi Fen Bilimleri Enstitüsü Dergisi 7(4), 309-315.

Beyzi, S.B., Ülger, İ., Kaliber, M. \& Konca, Y., 2018. Determination of chemical, nutritional and fermentation properties of citrus pulp silages. Turkish J Agric. Food Sci. Tech. 6(12), 1833-1837.

Bölükbaş, B. \& Kaya, I., 2018. Composition of rice straw and methods of increasing its feed value. Lalahan Hayvancllık Araştırma Enstitüsü Dergisi. 58(2), 99-107.

Emeksizoğlu, B., 2016. Kastamonu yöresinde yetiştirilen einkorn (Triticum monococcum L.) buğdayının bazı kalite özellikleri ile bazlama ve erişte yapımında kullanımının araştıııması. Doktora Tezi, Ondokuz Mayıs Üniversitesi Fen Bilimleri Enstitüsü, Gıda Mühendisliği Anabilim Dalı, Samsun.

Ergül, Ş., Ayaşan, T., Ülger, I., Kaliber, M., Barut, H., Aykanat, S., Ezici, A.A., Yaktubay, Ş. \& Dinçer, M. N., 2017. Determination of the nutritive value of some bread wheat varieties developed in East Mediterranean Agricultural Research Institute using in vitro gas production technique. Türk Tarım ve Doğa Bilimleri Dergisi. 4(4), 441-446.

Hart, P.W., 2020. Wheat straw as an alternative pulp fiber. Tappi J. 19(1), 41-52.

Hu, J., Cui, X., Dai, J., Wang, J., Chen, R., Yin, R. \& Lin, X., 2014. Interactive effects of arbuscular mycorrhizae and maize (Zea mays L.) straws on wheat (Triticum aestivum L.) growth and organic carbon storage in a sandy loam soil. Soil Water Resources 3, 119-126.

Goering, M.K. \& Van Soest, P.J., 1970. Forage fiber analysis (apparatus, reagents, procedures and some applications). Agricultural Handbook No 379. Agricultural Research Services, USDA, Washington, DC.

Kalkan, H. \& Filya, I., 2011. Effects of cellulase enzyme on nutritive value, in vitro digestion characteristics and microbial biomass production of wheat straw. Kafkas Üniversitesi Veteriner Fakültesi Dergisi 17 (4), 585-594. 
Menke, K.H. \& Steingass, H., 1988. Estimation of the energetic feed value obtained from chemical analysis and in vitro gas production using rumen fluid. Anim. Res. Devel. 28, 7-55.

Milestone. 2009. Milestone SK-10 and SK-12 Rotors user manual. Sorisole, Italy, Milestone.

Mishra, O.P., Tripathi, S.K. \& Bhardwaj, N.K., 2020. Suitability of corn stalk pulp for improving physical strength properties of agro-residue pulp. Cellulose Chem. Technol. 54(1-2), 65-71.

Orskov, E.R. \& McDonald, I., 1979. The estimation of protein degradability in the rumen from incubation measurements weighted according to rate of passage. J. Agric. Sci. 92, 499-503.

Özcan, H. \& Taban, S., 2000. Effects of VA-mycorrhiza on growth and phosphorus, zinc, iron, copper and manganese concentrations of maize grown in acid and alkaline soils. Turkish J. Agric. Forestry 24, 629-635.

Pellegrino, E., Opik, M., Bonari, E. \& Ercoli, L., 2015. Responses of wheat to arbuscular mycorrhizal fungi: A metaanalysis of field studies from 1975 to 2013 . Soil Biol. Biochem. 84, 210e217.

Sabia, E., Claps, S., Napolitano, F., Annicchiaricoa, G., Brunoa, A., Francavigliac, R., Sepea L. \& Aleandri, L., 2015. In vivo digestibility of two different forage species inoculated with arbuscular mycorrhiza in Mediterranean red goats. Small Ruminant Res. 123(1), 83-87.

Şanal, T., 2018. Bazı yerel buğday çeşitlerinin kalite parametreleri. TÜRKTOB Dergisi. 38-43.

Schenck, N.C. \& Perez, Y., 1990. Manual for the Identification of VA Mycorrhizal Fungi. Synergistic Publications, Gainesville, Florida, USA, pp. 286.

Scott, J. M., Hill, C.B., \& Jessop, R.S. 1991. Growth chamber study of phosphorus applied as drilled granules or as seed coatings to wheat sown in soils differing in P-sorption capacity. Fertilizer Res. 29, 281-287.

Shrivastava, B., Jain, K.K., Kalra, A. \& Kuhad R.C., 2014. Bioprocessing of wheat straw into nutritionally rich and digested cattle feed. Sci. Rep. 4,6360. doi:10.1038/srep06360

Smith, S. \& Read, D.J, 2008. Mycorrhizal symbiosis. Academic Press, San Diego, California.

Somenahallya, A., DuPontb, J.I., Bradyc, J., McLawrencea, J., Northupb, B. \& Gowda, P., 2018. Microbial communities in soil profile are more responsive to legacy effects of wheat-cover crop rotations than tillage systems. Soil Biol. Biochem. 123, 126-135.

Ülger, I., Kamalak, A., Kaya, E. \& Kurt, O., 2017. Comparison of chemical composition and anti-methanogenic potential of Liquidambar orientalis leaves with Laurus nobilis and Eucalyptus globulus leaves using in vitro gas production technique. Ciencia e Investigación Agraria. 44(1), 75-82.

Ülger, I., Kaliber, M., Ayaşan, T. \& Küçük, O., 2018. Chemical composition, organic matter digestibility and energy content of apple pomace silage and its combination with corn plant, sugar beet pulp and pumpkin pulp. S. Afr. J. Anim. Sci. 48(3), 497-503.

Tang, W., Wu, X., Huang, C., Huang, C., Lai, C. \& Yong, Q., 2019. Enhancing enzymatic digestibility of waste wheat straw by pre-soaking to reduce the ash-influencing effect on autohydrolysis. Biotechnol. Biofuels. 12(222), 1-12.

Van Soest, P.J., Robertson, J.B. \& Lewis, B.A., 1991. Methods for dietary fiber, neutral detergent fiber, and nonstarch polysaccharides in relation to animal nutrition. J. Dairy Sci. 74(10), 3583-3597.

Zayed, M.S., 2018. Enhancement the feeding value of rice straw as animal fodder through microbial inoculants and physical treatments. Int. J. Recycl. Org. Waste Agric. 7, 117-124. https://doi.org/10.1007/s40093-018-0197-7

Zheng, Q., Zhou, T., Wang, Y., Cao, X., Wu, S., Meili Zhao, M., Wang, H., Xu, M., Zheng, B., Zheng, J. \& Guan, X., 2018. Pre-treatment of wheat straw leads to structural changes and improved enzymatic hydrolysis. Sci. Rep. 8 , 1321. 